\title{
COMPARATIVE STUDY BETWEEN OPEN AND LAPAROSCOPIC APPENDECTOMY IN SILCHAR MEDICAL COLLEGE AND HOSPITAL
}

\author{
Siddhartha Sankar Bhattacharjee1, Khorshid Alam Hussain²
}

${ }_{1}^{1}$ Associate Professor, Department of Surgery, Silchar Medical College and Hospital, Silchar, Assam, India.

${ }^{2}$ Postgraduate Trainee, Department of Surgery, Silchar Medical College and Hospital, Silchar, Assam, India.

\begin{abstract}
BACKGROUND
Appendectomy is the most common operation performed by general surgeons. Open appendectomy has been the gold standard since its advent, but it is being gradually replaced by laparoscopic appendectomy. However, none of the surgical methods has been established as superior.

Aim-This study aims to compare the outcome of open and laparoscopic appendectomy carried in our institution.
\end{abstract}

ABSTRACT

\section{MATERIALS AND METHODS}

This non-randomised controlled trial comprising of 100 patients of acute and recurrent appendicitis was carried out in Silchar Medical College and Hospital from September 2014 to August 2015. They were randomly divided into two groups-A (Open) and B (Laparoscopic). Both the groups were compared on the basis of operation time, length of hospital stay, postoperative pain, return to normal activity, postoperative complications, cosmesis and cost of operation.

\section{RESULTS}

Age and sex of both groups were comparable. Mean operative time was $30.6 \pm 6.099$ mins for open and $44.42 \pm 6.973$ mins for laparoscopic group. The mean postoperative pain using VAS $(0-10)$ at the end of 24 hours postoperatively was $2.560 \pm 0.850$ in cases of LA. In cases of OA the mean VAS $(0-10)$ value was $4.140 \pm 0.969$, the mean postoperative length of stay in case of LA was $2.02 \pm 0.685$ ranging from 1-3 days and in case of $0 A$ mean value was 3.7 \pm 1.015 ranging from 2-6 days. The mean duration of return to normal day-to-day activity was $9.52 \pm 1.34$ days in case of LA ranging from 7-12 days. In case of OA, mean value was $19.22 \pm 1.718$ days ranging from 15-23 days. Postoperative complication was more in open group. Cosmesis was better in laparoscopic group. Cost of surgery was higher in laparoscopic group.

\section{CONCLUSION}

Laparoscopic appendectomy is better in terms of shorter hospital stay; less postoperative pain, better cosmesis, early return to normal activity and less postoperative complications, but the greater operating time and expenditure is a disadvantage.

\section{KEY WORDS}

OA-Open Appendectomy, LA-Laparoscopic Appendectomy, VAS-Visual Analogue Scale, CBC-Complete Blood Count, RBS-Random Blood Sugar, ECG-Electrocardiogram, CXR-Chest X-Ray.

HOW TO CITE THIS ARTICLE: Bhattacharjee SS, Hussain KA. Comparative study between open and laparoscopic appendectomy in Silchar Medical College and Hospital. J. Evolution Med. Dent. Sci. 2018;7(46):5039-5044, DOI: 10.14260/jemds/2018/1121

\section{BACKGROUND}

This study of the poet Zeta says the following about acute appendicitis in 'The Diagnosis of Acute Abdomen in Rhyme.'1 Of all the ills within the abdomen which cause affliction to the sons of men, there is none more often puts them in a fix than trouble in the worm-like appendix-that caecal tail which sometimes tells a story or figures in a scene which may be gory; that arch-deceiver, symbol of the devil which leads to every kind of septic evil; that unexploded bomb which soon or late aperients may serve to detonate; that worm which often turns to bad effect and makes us treat it with a great respect; that foul assassin whose supreme delight choosing the place and knowing well the site to stab below the belt and on the right is causing that dread disease-appendicitis.

'Financial or Other Competing Interest': None.

Submission 02-10-2018, Peer Review 27-10-2018,

Acceptance 02-11-2018, Published 12-11-2018.

Corresponding Author:

Dr. Khorshid Alam Hussain,

House No. 49, Bishnujyoti Path,

Hatigaon, Guwahati-781038,

Assam, India.

E-mail: kurkure12@gmail.com

DOI: $10.14260 /$ jemds $/ 2018 / 1121$

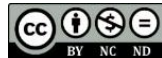

Appendicitis is one of the best known medical entities and yet one of the most difficult diagnostic problems to confront often requiring removal of the inflamed appendix. It is sometimes confusing and often a treacherous cause of acute abdomen at all ages, which requires utmost skill and care of the attending surgeon besides good clinical evaluation. ${ }^{2}$ Appendicitis is an inflammation of the vermiform appendix. It is mostly caused by obstruction of the lumen due to hyperplasia of the lymphoid follicles at younger age or by obstruction of the lumen by faecoliths in older patients.

Appendectomy is the most commonly performed emergency operation worldwide with a lifetime risk of appendicitis of $8.6 \%$ in males and $6.7 \%$ in females (Flum and Koepsell 2002; Addiss et al 1990).3,4

Appendectomy carries a complication rate of $4-15 \%$, as well as associated costs and the discomfort of hospitalisation and surgery. Therefore, the goal of the surgeon is to make an accurate diagnosis as early as possible. Delayed diagnosis and treatment account for much of the mortality and morbidity associated with appendicitis. The overall mortality rate of $0.2-0.8 \%$ is attributable to complications of the disease rather than to surgical intervention. The mortality rate in children ranges from $0.1 \%$ to $1 \%$; in patients older than 70 years the 
rate rises above $20 \%$, primarily because of diagnostic and therapeutic delay. ${ }^{5}$

Appendiceal perforation is associated with increased morbidity and mortality compared with non-perforating appendicitis. The mortality risk of acute but not gangrenous appendicitis is less than $0.1 \%$, but the risk rises to $0.6 \%$ in gangrenous appendicitis. The rate of perforation varies from $16 \%$ to $40 \%$ with a higher frequency occurring in younger age groups $(40-57 \%)$ and in patients older than 50 years (55$70 \%$ ), in whom misdiagnosis and delayed diagnosis are common. Complications occur in $1-5 \%$ of patients with appendicitis and postoperative wound infections account for almost one-third of the associated morbidity. ${ }^{6}$ Immediate appendectomy has long been the recommended treatment for acute appendicitis, because of the presumed risk of progression to rupture.

For almost a century, open appendectomy (OA), first described by Charles McBurney in 1889, has remained the gold standard treatment for acute appendicitis.

Laparoscopic appendectomy was first described by Kurt Semm in $1983^{7}$ and the application of the laparoscopic approach for acute appendicitis was first reported by Schreiber in 19878 with advances in technology and the surgical technique, laparoscopic appendectomy has become the novel alternative in the treatment of appendicitis in the last 3 decades. Despite the publications of numerous randomised trials, which compared open and laparoscopic appendectomy, the superiority of laparoscopy appendectomy in patients with suspected appendicitis remain controversial.

McBurney's operation is well tolerated with less comorbidity. The benefits of laparoscopic appendicectomy have been difficult to establish. The putative advantages of the laparoscopic approach are quicker and less painful recovery, fewer postoperative complications and better cosmesis with few drawbacks such as longer duration of surgery and high cost. 9

In our institution appendectomy is one of the common surgeries performed. This study aims at comparing the efficiency of open and laparoscopic appendectomy for the treatment of acute and recurrent appendicitis and to arrive at a conclusion as to the best modality of treatment after comparison morbidity in relation to standard published material.

\section{Aims and Objectives}

The aim of the study is to compare the effectiveness of laparoscopic and open appendectomy in the treatment of acute and recurrent appendicitis. The following parameters are to be evaluated for both laparoscopic and open procedures-

1. Duration of procedure.

2. Post-operative pain.

3. Post-operative length of hospital stay.

4. Complications.

5. Subjective full recovery and return to normal activity.

6. Cost analysis.

7. Cosmesis.

\section{MATERIALS AND METHODS}

This non-randomised controlled trial was conducted in the Department of General Surgery. Silchar Medical College and Hospital, Silchar for a period of one year from $20^{\text {th }}$ July 2015 to $20^{\text {th }}$ July 2016 .
The study protocol was approved by the Institutional Ethics Committee.

\section{Source of Data}

All patients attending surgery outpatient department and emergency department of Silchar Medical College and Hospital, Silchar, Assam.

\section{Inclusion Criteria}

1. All confirmed cases of acute and recurrent appendicitis that came to surgery outpatient department and emergency department.

2. Patients with no other systemic illness.

3. Patients willing to be enrolled in the study and have signed the consent form.

\section{Exclusion Criteria}

1. Patients with absolute contraindications to laparoscopic surgery.

2. Absolute contraindications to general anaesthesia.

3. Pregnant females.

All the patients included in the study were evaluated by a thorough history and physical examination. In addition to routine blood investigations which included $\mathrm{CBC}$, serum creatinine, RBS, ECG, CXR, radiological investigation like ultrasonography was also done.

The patients were randomised into two groups of laparoscopic appendectomy and open appendectomy constituting of 50 cases in each group. A single dose of preoperative antibiotic was given followed by same for 3 days postoperatively or less. Analgesic like diclofenac injection was given postoperatively for 2 days or less/SOS

Open appendectomy was done by standard method with a Gridiron incision muscles split, Peritoneum tented, opened, the appendix identified, securing the mesoappendix with 2-0 silk and cutting off the mesoappendix. Appendix was crushed at its base, ligature tied and cut. Haemostasis achieved and peritoneum and muscles closed with Vicryl and skin with nylon suture.

Laparoscopic appendectomy was done by three ports. Pneumoperitoneum created by Veress needle through an umbilical incision or by Hasson open technique. $10 \mathrm{~mm}$ port inserted in umbilical incision for 30-degree scope with camera, second $5 \mathrm{~mm}$ port in McBurney point in right iliac fossa and a third $10 \mathrm{~mm}$ port in suprapubic region.

Appendix skeletonised by bipolar cauterisation with harmonic, mesoappendix was cauterised till base. Base ligated with Endoloops of $1 / 0$ chromic catgut. Appendix cut between $2^{\text {nd }}$ and $3^{\text {rd }}$ Endoloop ligature and extracted through $10 \mathrm{~mm}$ port. Haemostasis was achieved and diagnostic laparoscopy was done and ports were removed and port site was sutured by $3 / 0$ Nylon sutures. Operative time was calculated from the incision to complete closure of the wound.

Post-operative pain was assessed by using a Visual analog scoring system from $0-10$ with 0 indicating no pain and 10 indicating highest severity of pain at 24 hours postoperative period.

Postoperative duration of hospital stay was measured in days starting from day of operation to the day of discharge. 
Complications were observed intraoperatively and postoperatively in terms of wound infection, ileus, intraabdominal abscess and visceral or vascular injury.

Return to normal activity was measured in days and defined as return to usual activity of domestic and social life of the patients.

Cost analysis was obtained from hospital billing records. Hospital charges represented the sum of all charges assessed to the patient during their hospitalisation such as the fee assessed for bed occupancy, operating room charges (Including fees for total time in the operating room and all equipment charges).

Cosmesis was defined by external appearance and nature of healing of wound, either as normal healing or abnormal healing, which included hypertrophic scar or keloid.

The patients were discharged when tolerated oral feed and deemed fit and was asked to come for regular follow-up after 7 days then 1, 3, 6, 9, 12 months postoperatively. Data was analysed using software SPSS. A p-value less than 0.05 was considered significant. The sample size was taken for convenience. Since the duration of the study was few months, the patients were selected by convenience and taken also done at conveniences.

\section{Statistical Analysis}

All observations were tabulated and analysed using independent student's ' $t$ ' test. In Statistical Package for Social Sciences (SPSS) software version 22, statistically significant difference in findings was considered when $p$-value was $<0.05$.

\section{RESULTS}

Age and sex of both groups were comparable. Mean operative

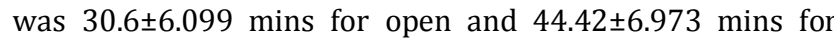
laparoscopic group. The mean postoperative pain using VAS $(0-10)$ at end of 24 hours postoperatively was $2.560 \pm 0.850$ in cases of LA. In cases of OA the mean VAS (0-10) value was $4.140 \pm 0.969$, the mean postoperative length of stay in case of LA was $2.02 \pm 0.685$ ranging from 1-3 days and in case of $\mathrm{OA}$ mean value was $3.7 \pm 1.015$ ranging from $2-6$ days. The mean duration of return to normal day-to-day activity was $9.52 \pm 1.34$ days in case of LA ranging from 7-12 days. In case of OA, mean value was $19.22 \pm 1.718$ days ranging from $15-23$ days. Postoperative complication was more in open group. Cosmesis was better in laparoscopic group. Cost of surgery was higher in laparoscopic group.

\section{DISCUSSION}

\section{Duration of Surgery}

In the present study, the mean duration of surgery in cases of LA was 44.42 mins \pm 8.52 mins. In cases of $\mathrm{OA}$, the mean duration of surgery was 30.08 mins \pm 9.185 mins with a difference of 14.34 mins between the two procedures. The pvalue was $<0.0001$, which is statistically significant. This study showed that open appendectomy is less time consuming than laparoscopic appendectomy.

Similar observation were reported by Seraj Ahmed et al,10 Sandeep Thakre et $\mathrm{al}^{11}$ Geetha $\mathrm{KR}^{9}$ et al, Yong JL et al ${ }^{12}$ and others.
Generally, all Laparoscopic Procedures are More Time Consuming for the following Reasons:

1. Inherent nature of slow manoeuvre of laparoscopic techniques.

2. Time taken by careful slow insufflations.

3. Routine diagnostic laparoscopy before starting any laparoscopic procedure.

Time in Minutes (Mean)

\begin{tabular}{|c|c|c|c|}
\hline Study & $\begin{array}{c}\text { Open } \\
\text { Appendectomy } \\
\mathbf{N = 5 0}\end{array}$ & $\begin{array}{c}\text { Lap } \\
\text { Appendectomy } \\
\mathbf{N = 5 0}\end{array}$ & P value \\
\hline $\begin{array}{c}\text { Seraj Ahmed } \\
\text { et al (2016) }\end{array}$ & $46 \pm 43$ & $64 \pm 9$ & 0.0003 \\
\hline $\begin{array}{c}\text { Sandeep Thakre } \\
\text { et al (2014) }\end{array}$ & $45 \pm 7$ & $60 \pm 8$ & $<0.017$ \\
\hline $\begin{array}{c}\text { Geetha KR } \\
\text { et al (2009) }\end{array}$ & $58 \pm 29$ & $74 \pm 13$ & $<0.0001$ \\
\hline $\begin{array}{c}\text { Yong JL et al } \\
\text { (2006) }\end{array}$ & $60 \pm 25$ & $80 \pm 02$ & $<.005$ \\
\hline $\begin{array}{c}\text { Marzouk M, et al } \\
\text { (2003) }\end{array}$ & $59 \pm 4$ & $67 \pm 3$ & $<.005$ \\
\hline $\begin{array}{c}\text { Heinzelmann M, } \\
\text { et al (1995) }\end{array}$ & $64 \pm 12$ & $83 \pm 15$ & $<.001$ \\
\hline $\begin{array}{c}\text { Present study } \\
\text { (2016) }\end{array}$ & $30 \pm 08$ & $44 \pm 42$ & $<0.0001$ \\
\hline
\end{tabular}

\section{Postoperative Pain}

In this study, the postoperative pain was estimated by using Visual Analogue Scale at 24 hours postoperatively. The mean postoperative pain using VAS (0-10) at end of 24 hours postoperatively was $2.560 \pm 0.850$ in cases of LA. In cases of $\mathrm{OA}$, the mean VAS $(0-10)$ value was $4.140 \pm 0.969$.

The findings in this study were concordant with the other studies conducted by Hellberg A et al,13 Seraj Ahmed et al, Ortega et al,14 McAnena et al ${ }^{15}$ and others.

Laparoscopic appendectomy reduces postoperative pain, since the trocar orifices are less traumatic than incisions with muscle division and there is therefore a smaller amount of tissue trauma. Larger incisions in case of open appendectomy also aids in increase in postoperative pain.

\section{(Mean Visual Analogue Score for Pain 0-10)}

\begin{tabular}{|c|c|c|c|}
\hline Study & $\begin{array}{c}\text { Open } \\
\text { Appendectomy } \\
\mathbf{N = 5 0}\end{array}$ & $\begin{array}{c}\text { Lap } \\
\text { Appendectomy } \\
\mathbf{N = 5 0}\end{array}$ & P value \\
\hline $\begin{array}{c}\text { Seraj Ahmed } \\
\text { et al (2016) }\end{array}$ & $4 \pm 13$ & $3 \pm 25$ & .0485 \\
\hline $\begin{array}{c}\text { Hellberg A } \\
\text { et al (1999) }\end{array}$ & $4 \pm 2$ & $3 \pm 6$ & $<.002$ \\
\hline $\begin{array}{c}\text { Sandeep Thakre } \\
\text { et al (2014) }\end{array}$ & $4 \pm 8$ & $3 \pm 2$ & $<0.093$ \\
\hline Ingty et al (2016) & $2 \pm 72$ & $1 \pm 28$ & $<.05$ \\
\hline Present study & $4 \pm 14$ & $2 \pm 56$ & $<0.0001$ \\
\hline
\end{tabular}

\section{Postoperative Length of Hospital Stay (Mean Duration in Days)}

In the present study, the mean post-operative length of stay in case of LA was $2.02 \pm 0.685$ ranging from 1-3 days and in case of $\mathrm{OA}$ mean value was $3.7 \pm 1.015$ ranging from 2-6 days. Similar results were also demonstrated by the following studies mentioned below- 


\begin{tabular}{|c|c|c|c|}
\hline Study & $\begin{array}{c}\text { Open } \\
\text { Appendectomy } \\
\mathbf{N = 5 0}\end{array}$ & $\begin{array}{c}\text { Lap } \\
\text { Appendectomy } \\
\mathbf{N = 5 0}\end{array}$ & P value \\
\hline $\begin{array}{c}\text { Cox MR et al } \\
(1996)\end{array}$ & $3 \pm 8$ & $2 \pm 9$ & 0.045 \\
\hline $\begin{array}{c}\text { Azaro EM } \\
\text { et al (1999) }\end{array}$ & $5 \pm 01$ & $3 \pm 9$ & 0.006 \\
\hline $\begin{array}{c}\text { Yong JL } \\
\text { et al (2006) }\end{array}$ & $4 \pm 0$ & $3 \pm 0$ & $<0.037$ \\
\hline $\begin{array}{c}\text { Long et al } \\
(2001)\end{array}$ & $3 \pm 4$ & $2 \pm 6$ & $<0.01$ \\
\hline $\begin{array}{c}\text { Geetha KR } \\
\text { et al (2009) }\end{array}$ & $4 \pm 36$ & $3 \pm 13$ & $<.0001$ \\
\hline Present Study & $3 \pm 7$ & $2 \pm 02$ & $<0.0001$ \\
\hline
\end{tabular}

Shorter postoperative stay in hospital in case of LA can be attributed to reduced pain and trauma following surgery, lesser rate of complications, hence less postoperative morbidity as well as early tolerance to oral feeds. However, a study conducted by Golub and colleagues (1998) ${ }^{16}$ demonstrate that there is not much significant difference between postoperative stay in cases of LA and OA

\section{Postoperative Complications}

Out of the 50 cases that underwent LA, 4 cases (8\%) developed postoperative complications and 12 (24\%) cases developed complications in case of OA. Laparoscopic appendectomy confers advantages in terms of fewer postoperative complications. This finding was similar when compared to other studies conducted by McAnena OJ et al 1995; Minutolo, Vincenzo, et al 201417; Azaro EM et al (1999) ${ }^{18}$ and others.

However, in some studies conducted by Yong JL et al 2005, Katkhouda et $\mathrm{al}^{19}$ and Heinzelmann et $\mathrm{al}^{20}$ showed no significant difference between the complication rates of open and laparoscopic appendectomy.

\begin{tabular}{|c|c|c|c|}
\hline Study & $\begin{array}{c}\text { Open } \\
\text { Appendectomy } \\
\text { (\%) N=50 }\end{array}$ & $\begin{array}{c}\text { Lap } \\
\text { Appendectomy } \\
\text { (\%) N=50 }\end{array}$ & P value \\
\hline $\begin{array}{c}\text { McAnena 0J, } \\
\text { et al (1995) }\end{array}$ & 11 & 4 & $<0.05$ \\
\hline $\begin{array}{c}\text { Minutolo, } \\
\text { Vincenzo } \\
\text { et al (2014) }\end{array}$ & 13.2 & 2.9 & 0.006 \\
\hline $\begin{array}{c}\text { Azaro EM } \\
\text { et al (1999) }\end{array}$ & 18.3 & 6.9 & $<0.05$ \\
\hline $\begin{array}{c}\text { Yong JL } \\
\text { et al (2005) }\end{array}$ & 15.1 & 13.4 & 0.734 \\
\hline $\begin{array}{c}\text { KJ Sweeney } \\
\text { et al (2006) }\end{array}$ & 19 & 4 & 0.02 \\
\hline $\begin{array}{c}\text { Biondi } \\
\text { et al (2016) }\end{array}$ & 10.6 & 1.4 & $<0.001$ \\
\hline Present Study & 24 & 8 & $<0.05$ \\
\hline
\end{tabular}

In cases of LA, infection is significantly less due to lack of contamination to the abdominal wall. The extraction of specimen with a bag through a trocar port rather than directly through the surgical wound as in OA can explain the reduction in incidence. Moreover, the smaller size of the laparoscopic incisions reduces the probability of infection.

\section{Return to Normal Activity (Mean Duration in Days)}

In this study, the mean duration of return to normal day-today activity was $9.52 \pm 1.34$ days in case of LA ranging from 712 days. In case of $\mathrm{OA}$, mean value was $19.22 \pm 1.718$ days ranging from 15-23 days. Earlier return to normal activity in cases of LA can be attributed to less postoperative pain, early tolerance to oral feed or lesser postoperative complications rates leading to early ambulation.

Similar findings have also been reported by studies conducted by Ortega et al 1995, Cox MR et $\mathrm{al}^{21}$ (1996), Long et al (2001),22 Geetha KR et $\mathrm{al}^{9}$ (2009), Biondi et al ${ }^{23}$ (2016) and others.

\begin{tabular}{|c|c|c|c|}
\hline Study & $\begin{array}{c}\text { Open } \\
\text { Appendectomy } \\
\mathbf{N = 5 0}\end{array}$ & $\begin{array}{c}\text { Lap } \\
\text { Appendectomy } \\
\mathbf{N = 5 0}\end{array}$ & P value \\
\hline $\begin{array}{c}\text { Ortega } \\
\text { et al (1995) }\end{array}$ & 14 & 9 & $<0.001$ \\
\hline $\begin{array}{c}\text { Cox MR } \\
\text { et al (1996) }\end{array}$ & 19.7 & 10.4 & 0.001 \\
\hline $\begin{array}{c}\text { Long et al } \\
\text { (2001) }\end{array}$ & 21 & 14 & $<0.02$ \\
\hline $\begin{array}{c}\text { Ingty et al } 24 \\
\text { 2016 }\end{array}$ & 20.80 & 13.52 & $<0.05$ \\
\hline $\begin{array}{c}\text { Geetha KR et al } \\
\text { (2009) }\end{array}$ & 19.44 & 13.86 & $<0.0001$ \\
\hline Present Study & 19.22 & 9.52 & $<0.0001$ \\
\hline
\end{tabular}

\section{Cost Analysis (In Rupees)}

In this study, the mean cost for the surgery in case of LA was Rs. $5960 \pm 482.76$. In case of $\mathrm{OA}$, the mean value was Rs. $4350 \pm 507.59$. The cost of LA is significantly higher as compared to OA. These findings are also supported from the studies given below in the table.

\begin{tabular}{|c|c|c|c|}
\hline Study & $\begin{array}{c}\text { Open } \\
\text { Appendectomy } \\
\text { (RS) N=50 }\end{array}$ & $\begin{array}{c}\text { Lap } \\
\text { Appendectomy } \\
\text { (Rs) N=50 }\end{array}$ & P value \\
\hline $\begin{array}{c}\text { Manjunath } \\
\text { et al25 (2016) }\end{array}$ & 11766 & 17079 & 0.0001 \\
\hline $\begin{array}{c}\text { Rakesh Rai } \\
\text { et al26 (2016) }\end{array}$ & 15842 & 8355 & $<0.000$ \\
\hline $\begin{array}{c}\text { Geetha KR } \\
\text { et al (2009) }\end{array}$ & 4225.81 & 5560.92 & $<0.0001$ \\
\hline Present Study & 4350 & 5960 & $<0.0001$ \\
\hline
\end{tabular}

Laparoscopy is assumed to be more costly due to longer duration of surgery, expensive surgical disposable equipment and additional costs in case of conversion to laparotomy. However, the increase in cost is compensated by shorter duration of post-operative hospital stay, lesser post-operative complication, hence lesser morbidity and early resumption to normal daily activities.

\section{Cosmesis}

In this present study 4 out of 50 cases that underwent LA developed hypertrophic scar, whereas in case of OA 12 out of 50 cases developed hypertrophic scar. LA is associated with better cosmesis when compared to OA. Similar findings were reported in study conducted by Sucullu et al, ${ }^{27}$ Hebebrand et al. ${ }^{28}$

The reason for better cosmesis is small incision size and strategically placed incisions in cases of LA and lesser incidence of postoperative wound infections in LA. 


\section{CONCLUSION}

The study titled- "Comparative Study between Open and Laparoscopic Appendectomy in Silchar Medical College and Hospital" was undertaken to compare the effectiveness of laparoscopic and open appendectomy in the treatment of acute and recurrent appendicitis.

Upon studying and reviewing various standard literature and by correlating them with our study, we have found a definite difference in outcome between open appendectomy and laparoscopic appendectomy.

Laparoscopic appendectomy was better than open appendectomy with respect to postoperative pain, lesser duration of postoperative hospital stay, lesser rate of wound infection and postoperative complications, earlier return to normal day-to-day activities and better cosmesis. Although, above-mentioned advantages were at the cost of slightly increased duration of operative time and cost of surgery. However, the above-mentioned advantages outweigh the time and cost drawback for laparoscopic appendectomy.

Going by our study, we definitely find an overall advantage in laparoscopic appendectomy.

We conclude that the change in the surgical approach from open to laparoscopic appendectomy in management cases of uncomplicated appendicitis is safe and effective.

\section{REFERENCES}

[1] Zeta. The acute abdomen in rhyme. 2nd edn. London: HK Lewis \& Co. Ltd., 1949.

[2] Williams RA, Myers P. Monograph - pathology of appendix. $1^{\text {st }}$ edn. Chapman and Hall Inc., 1994.

[3] Flum DR, Koepsell T. The clinical and economic correlates of misdiagnosed appendicitis: Nationwide analysis. Arch Surg 2002;137(7):799-804.

[4] Addiss DG, Shaffer N, Fowler BS, et al. The epidemiology of appendicitis and appendectomy in the United States. Am J Epidemiol 1990;132(5):910-25.

[5] Brunicardi F, Andersen D, Billiar T, et al. Schwartz's Principles of surgery. $9^{\text {th }}$ edn. McGraw-Hill Professional 2009.

[6] http://emedicine.medscape.com/article/773895clinical.

[7] Semm K. Endoscopic appendectomy. Endoscopy 1983;15(2):59-64.

[8] Schreiber JH. Early experience with laparoscopic appendectomy in women. Surg Endosc 1987;1(4):2116.

[9] Geetha KR, Kudva A, Bhavatej. Laparoscopic appendicectomy versus open appendicectomy: a comparative study of clinical outcome and cost analysis - Institutional experience. The Indian Journal of Surgery 2009;71(3):142-6.

[10] Seraj A, Akhil KG, Sohan PS, et al. Comparative study between open versus laparoscopic appendicectomy in western U.P. Sch J App Med Sci 2016;4(4B):1248-54.

[11] Thakre S, Mujalde VS, Mudgal MM, et al. A comparative study between laparoscopic appendectomy and conventional open appendectomy. Scholars Journal of Applied Medical Sciences (SJAMS) 2014;2(5F):190912.
[12] Yong JL, Law WL, Lo CY, et al. A comparative study of routine laparoscopic versus open appendectomy. Department of Surgery, University of Hong Kong Medical Centre, Queen Mary Hospital, Hong Kong, China. JSLS 2006;10(2):188-92.

[13] Hellberg A, Rudberg C, Kullman E, et al. Prospective randomized multicentre study of laparoscopic versus open appendicectomy. Br J Surg 1999;86(1):48-53.

[14] Ortega AE, Hunter JG, Peters JH, et al. A prospective, randomized comparison of laparoscopic appendectomy with open appendectomy. Laparoscopic Appendectomy Study Group. The American Journal of Surgery 1995;169(2):208-13.

[15] McAnena OJ, Austin O, O'Connell PR, et al. Laparoscopic versus open appendicectomy: a prospective evaluation. British Journal of Surgery 1992:79(8):818-20.

[16] Golub R, Siddiqui F, Pohl D. Laparoscopic versus open appendectomy: a meta-analysis. Journal of the American College of Surgeons 1998;186(5):545-53.

[17] Minutolo V, Licciardello A, Di Stefano B, et al. Outcomes and cost analysis of laparoscopic versus open appendectomy for treatment of acute appendicitis: 4-years of experience in a district hospital. BMC Surgery 2014;14(1):14.

[18] Azaro EM, Amaral PC, Ettinger JE, et al. Laparoscopic versus open appendicectomy: a comparative study. JSLS 1999;3(4):279-83.

[19] Katkhouda N, Mason RJ, Towfigh S, et al. Laparoscopic versus open appendectomy: a prospective randomized double-blind study. Annuals of Surgery 2005;242(3):439-50.

[20] Heinzelmann M, Simmen HP, Cummins AS, et al. Is laparoscopic appendectomy the new 'gold standard'? Arch Surg 1995;130(7):782-5.

[21] Cox MR, McCall JL, Toouli J, et al. Prospective randomized comparison of open versus laparoscopic appendectomy in men. World J Surgery 1996;20(3):263-6.

[22] Long KH, Bannon MP, Zietlow SP, et al. A prospective randomized comparison of laparoscopic appendectomy with open appendectomy: clinical and economic analyses. Surgery 2001;129(4):390-400.

[23] Biondi A, Di Stefano C, Ferrara F, et al. Laparoscopic versus open appendectomy: a retrospective cohort study assessing outcomes and cost-effectiveness. World Journal of Emergency Surgery 2016;11(1):44.

[24] Ingty MD, Gorad KD, Bokil C, et al. Comparative study of laparoscopic versus open appendicectomy in a rural medical college. International $\mathrm{J}$ of Healthcare and Biomedical Research 2016;4(02):66-72.

[25] Manjunath A, Mookherjee A. Laprascopic versus open appendicectomy: an analysis of the surgical outcomes and cost efficacy in a tertiary care medical college hospital. International Journal of Contemporary Medical Research 2016;3(6):1696-700.

[26] Rakesh R, D'Souza RC, Vijin V, et al. An evaluation of the seasonal variation in acute appendicitis. JEMDS 2014;3(2):257-60. 


\section{Jemds.com}

[27] Sucullu I, Filiz AI, Canda AE, et al. Body image and cosmesis after laparoscopic or open appendectomy. Surgical Laparoscopy Endoscopy \& Percutaneous Techniques 2009;19(5):401-4.
Original Research Article

[28] Hebebrand D, Troidl H, Spangenberger W, et al. Laparoscopic or classical appendectomy? A prospective randomized study. Der Chirurg Zeitschrift fur alle Gebiete der operativen Medizen 1994;65(2):112-20. 